\title{
Efficient Nitrate Reduction in a Fluidized Electrochemical Reactor Promoted by Pd-Sn/AC Particles
}

\author{
Huachun Lan ${ }^{1}$ Xiaobin Liu ${ }^{1}$ Huijuan Liu ${ }^{1}$ Ruiping Liu' ${ }^{1}$ Chengzhi Hu ${ }^{1}$ \\ Jiuhui $\mathbf{Q u}{ }^{1}$
}

Received: 9 July 2015/Accepted: 25 August 2015/Published online: 24 September 2015

(c) Springer Science+Business Media New York 2015

\begin{abstract}
Pd}-\mathrm{Sn}$ modified activated carbon (Pd-Sn/AC) was prepared by impregnation of $\mathrm{Pd}$ and $\mathrm{Sn}$ salts onto AC followed by heat treatment. Based on scanning electron microscopy, transmission electron microscopy, and X-ray diffraction analysis, $\mathrm{Pd}-\mathrm{Sn}$ alloy was highly dispersed on the surface of AC with a atomic ratio of about 4.21. A double electrolysis cell was established and separated via a proton-exchange membrane. In the cathodic cell compartment, the as-prepared $\mathrm{Pd}-\mathrm{Sn} / \mathrm{AC}$ was used as particle electrodes where electrolytic reduction of nitrate was performed. A batch mode study showed that at an applied
\end{abstract}

current of $30 \mathrm{~mA}$ with $7.5 \mathrm{~g} / \mathrm{L}$ catalyst, over $90 \%$ of the nitrate could be reduced in $80 \mathrm{~min}$ when the nitrate initial concentration was $24.6 \mathrm{mg} / \mathrm{L}$. The electro-catalytic process of nitrate reduction could be satisfactorily described with a first-order kinetics model. With increasing applied current, the nitrate removal rate increased; whereas, the $\mathrm{NH}_{4}{ }^{+}$ concentration increased as well. The inhibition effect of coexisting anions and cations on nitrate reduction followed this order: $\mathrm{Fe}^{3+}>\mathrm{Mn}^{2+}>\mathrm{Ca}^{2+}>\mathrm{Na}^{+}$and $\mathrm{Cl}^{-}<\mathrm{SO}_{4}{ }^{2-}$ $<\mathrm{HCO}_{3}{ }^{-}$.

Graphical Abstract

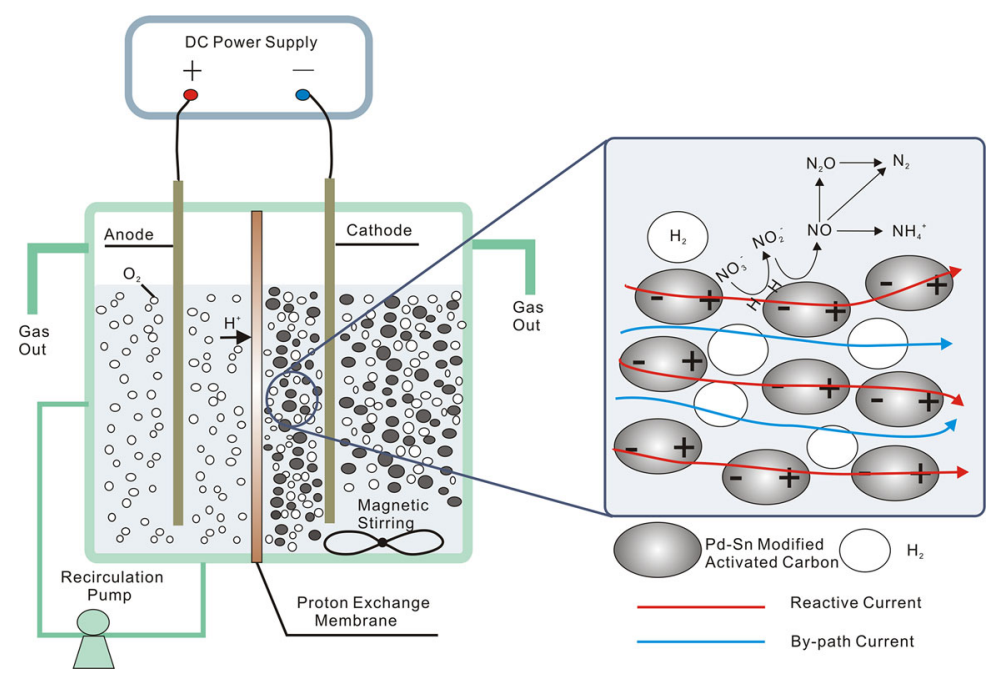

Chengzhi $\mathrm{Hu}$

czhu@rcees.ac.cn
Keywords Nitrate - Electrochemical reduction $\cdot \mathrm{Pd}-\mathrm{Sn} /$ $\mathrm{AC} \cdot$ Enhancement

1 Key Laboratory of Drinking Water Science and Technology, Research Center for Eco-Environmental Sciences, Chinese Academy of Sciences, Beijing 100085, China 


\section{Introduction}

With the development of industry and agriculture, nitrate has become the world's most widespread groundwater contaminant [1]. Nitrate can lead to methemoglobinemia when ingested by infants, and can even cause carcinoma, malformation and mutations when transformed into nitrosamines [2]. In China, the nitrate concentration of groundwater in some rural areas is higher than $40 \mathrm{mg} / \mathrm{L}$. It has been shown that the groundwater from 10 to $25 \%$ of the water-supply wells in a large region of the US exceeds the maximum contaminant level (MCL) for nitrate $(10 \mathrm{mg}$ $\mathrm{NO}_{3}{ }^{-}-\mathrm{N} / \mathrm{L}$ ) [3]. Therefore, remediation of nitrate-contaminated groundwater is an urgent priority.

Available methods for nitrate removal include physicochemical processes $[4,5]$ and biological denitrification $[6$, 7]. However, physico-chemical processes, such as ionexchange, reverse osmosis and electrodialysis, produce concentrated brine that must be treated or disposed of, and biological denitrification of drinking water is limited due to concerns with pathogens, turbidity, and chlorine demand in the treated water. Catalytic reduction of nitrate, including chemical catalytic methods and electrochemical catalytic methods, is emerging as the most promising and flexible technique to solve this problem [815].

Palladium (Pd)-based catalysts have excellent catalytic reduction activity, and can absorb and convert dihydrogen into atomic hydrogen $\left(\mathrm{H}^{*}\right)$ to reduce nitrate. In chemical catalytic processes, $\mathrm{H}_{2}$ gas acts as a hydrogen donor. Vorlop and co-workers discovered that nitrate could be reduced primarily to $\mathrm{N}_{2}$ with supported bimetallic hydrogenation catalysts [8]. Palladium was found to be the most active and selective metal for the reduction of nitrate, but the reduction of nitrate required a second metal as a co-catalyst [9]. $\mathrm{Pd}-\mathrm{Cu}, \mathrm{Pd}-\mathrm{Sn}$ and Pd-In coated on support materials such as $\mathrm{Al}_{2} \mathrm{O}_{3}$ or hydrotalcite have been shown to reduce nitrate when added to a solution along with hydrogen as an electron donor [8-15]. The catalytic reduction results in the production of nitrogen $\left(\mathrm{N}_{2}\right)$ gas and $\mathrm{NO}_{2}{ }^{-}$as intermediates [15]. However, past studies on chemical catalytic reduction have shown low hydrogen utilization efficiency, and difficult catalyst separation and reclamation steps are required.

Electro-catalytic reduction for nitrate removal is another promising method. In this process, $\mathrm{H}_{2}$ gas is produced on the cathode surface, which could be used in situ as a hydrogen donor. Various electrodes such as metals [16, 17], binary deposited metals [18], alloys [19], metal complexes [20] and synthetic diamond [21] have been studied in the electroreduction of nitrate. Vooys et al. [19] found that $\mathrm{Cu}$-modified Pd electrodes showed higher activity for nitrate reduction than single metal electrodes. Shimazu et al. [22] reported that Sn-modified $\mathrm{Pt}$ and Pd-Au electrodes exhibited the highest electrocatalytic activity. However, the non-affordability of these electrodes limits their application at an industrial scale and few studies were conducted to investigate the performance of $\mathrm{Pd}-\mathrm{Sn}$ in the electro-catalytic reduction for nitrate removal.

Hence, we combined the advantages of chemical catalytic and electro-catalytic reduction of nitrate in a threedimensional electrochemical reactor. $\mathrm{Pd}-\mathrm{Sn}$ bimetal modified activated carbon $(\mathrm{Pd}-\mathrm{Sn} / \mathrm{AC})$ was prepared and used as particle catalyst in the cathodic cell. Micro-electrolysis might take place on the cathodic side due to the presence of Pd-Sn/AC. Thus the surface of the cathode was expanded and the reduction process could be sped up on the micro-scale surface. The main objective of the present study was to examine the capability of this novel electro-catalytic reduction process with $\mathrm{Pd}-\mathrm{Sn} / \mathrm{AC}$ particle electrodes. In addition, the factors influencing nitrate reduction (such as applied current, initial nitrate concentration and co-existing ions/anions) were also investigated.

\section{Experimental}

\subsection{Preparation and Characterization of $\mathrm{Pd}-\mathrm{Sn} / \mathrm{AC}$ Electrodes}

$\mathrm{Pd}-\mathrm{Sn} / \mathrm{AC}(\mathrm{Pd}: \mathrm{Sn} \mathrm{w} / \mathrm{w}=4: 1$, the Pd content was $3 \mathrm{wt} \%$ with respect to $\mathrm{AC}$ ) was prepared by the following procedure: (1) the dried activated carbon was pretreated with $5 \%$ nitric acid for $2 \mathrm{~h}$, and after being washed to neutrality, the AC was dried at $120^{\circ} \mathrm{C}$; (2) Pd was deposited on the pretreated $\mathrm{AC}$ in a hydrochloric acid solution of $\mathrm{PdCl}_{2}$ (dihydrogen tetrachloropalladate (II), $\mathrm{H}_{2} \mathrm{PdCl}_{4}$ ), and then the sample was dried at $105{ }^{\circ} \mathrm{C}$ for $12 \mathrm{~h}$ and calcined at $350{ }^{\circ} \mathrm{C}$ for $2 \mathrm{~h}$; (3) the calcined samples were washed to remove chloride ions, which originated from either the impregnating solution or the decomposition of $\mathrm{H}_{2} \mathrm{PdCl}_{4}$ during drying; and (4) at room temperature, a desired amount of the second metal (Sn) was loaded from its chloride solution in the same manner, and the material was finally treated at $250{ }^{\circ} \mathrm{C}$ for $4 \mathrm{~h}$ with flowing hydrogen gas.

$\mathrm{The} \mathrm{Pd}-\mathrm{Sn} / \mathrm{AC}$ samples were examined with a scanning electron microscope with energy-dispersive X-ray spectroscopy (S-3000N, Hitachi). The surface areas of the samples were obtained with a Micromeritics apparatus, using the BET method. Transmission electron microscopy (TEM) was carried out using an H-7500 (Hitachi) 
microscope. X-ray powder diffraction (XRD) patterns of samples were obtained with an X'Pert PRO diffractometer, using $\mathrm{Cu}$ Ka radiation.

\subsection{Experimental Setup}

A schematic diagram of the electro-catalytic reactor was shown in Fig. 1. The anodic $(60 \mathrm{~mL})$ and cathodic $(60 \mathrm{~mL})$ cell compartments were separated by a proton-exchange membrane (GEFC-107, GEFC, China); the membrane was located at $1 \mathrm{~cm}$ distance from the anode and cathode, respectively. Both the anode and cathode were DSA (dimensionally stable anode) electrodes with $10 \mathrm{~cm}^{2}$ active surface area. The $\mathrm{Pd}-\mathrm{Sn} / \mathrm{AC}$ particles were suspended with a magnetic stirrer in the cathode cell. The water was continuously circulated by a recirculation pump in the anode cell. Direct current was supplied by a silicon rectifier (Model DH1718E-4, Beijing Dahua Electronic Instruments Group, Beijing, China). All experiments were conducted at an applied current of 10-50 mA and voltage between the electrodes of 1.5-6.5 V.

To keep the $\mathrm{pH}$ in the cathode cell stable, $0.014 \mathrm{M}$ $\mathrm{H}_{2} \mathrm{SO}_{4}$ solution was added to the anode cell. The $\mathrm{H}^{+}$in the anode cell compartment went through the proton-exchange membrane under the electric field to keep the $\mathrm{pH}$ in the cathode cell in the neutral range.
The reaction was started by adding a $\mathrm{NaNO}_{3}$ solution prepared with deionized water. $2 \mathrm{~mL}$ solutions were taken regularly from the reactor cell for analysis of $\mathrm{NO}_{3}{ }^{-}-\mathrm{N}$, $\mathrm{NO}_{2}{ }^{-}-\mathrm{N}$ and $\mathrm{NH}_{4}{ }^{+}-\mathrm{N}$.

\subsection{Analysis Method}

Samples were taken from the cathode compartment and filtered through a $0.45 \mu \mathrm{m}$ membrane. $\mathrm{NO}_{3}{ }^{-}-\mathrm{N}$ and $\mathrm{NO}_{2}{ }^{-}-\mathrm{N}$ were analyzed by ion chromatography (ICS2000, Dionex-4500i, USA). Ammonia was determined with a UV spectrophotometer. The $\mathrm{pH}$ was measured using a 9165BN pH electrode connected to an Orion- $828 \mathrm{pH}$ analyzer (Orion Research Inc., Beverly, MA, USA). After the reaction, the solution in the reactor was analyzed by ICP-OES (Perkin Elmer Company, Optima-2000DV) to quantify any dissolution of the active metals. The actual quantity of $\mathrm{Pd}$ and $\mathrm{Sn}$ deposited on the $\mathrm{AC}$ was analyzed as follows. First, the catalyst was dissolved in aqua regia $\left(\mathrm{HNO}_{3}: \mathrm{HCl}=1: 3\right)$. Then the solution was diluted to $1 \mathrm{~L}$. The quantity of $\mathrm{Pd}$ and $\mathrm{Sn}$ in the solution was measured by ICP-MS (Perkin Elmer Company, Optima-2000DV), which gave the actual amounts of Pd and Sn on the AC particles.

In our experiment, the possible gaseous products were $\mathrm{NO}, \mathrm{N}_{2} \mathrm{O}$ and $\mathrm{N}_{2}$, and the concentrations of $\mathrm{NO}$ and $\mathrm{N}_{2} \mathrm{O}$ were at trace levels, which was consistent with the results

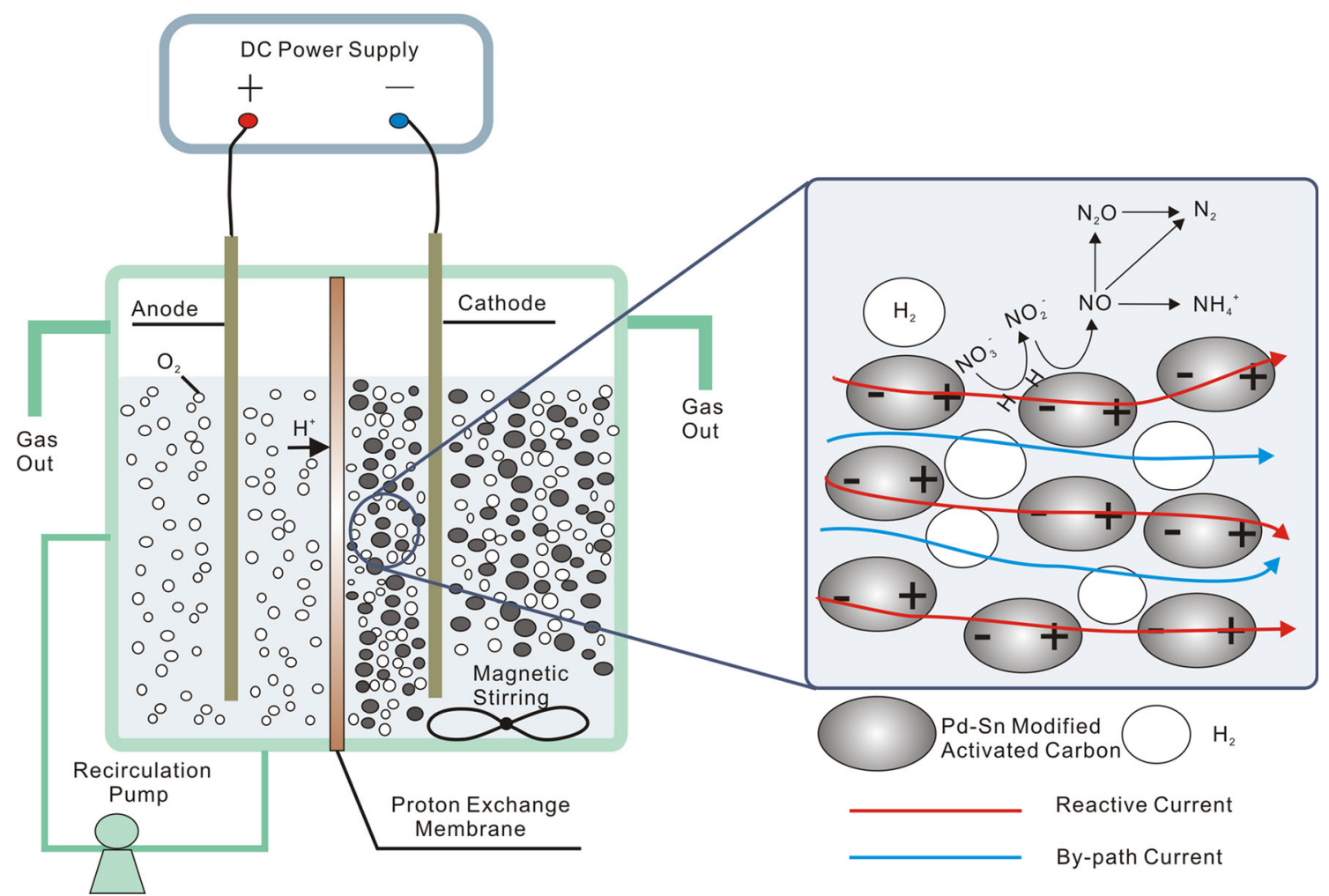

Fig. 1 Schematic diagram of electro-catalytic reactor based on $\mathrm{Pd}-\mathrm{Sn} / \mathrm{AC}$ particles 
reported by Wang [23]. So, in our study, the possible products $\mathrm{NO}$ and $\mathrm{N}_{2} \mathrm{O}$ were ignored.

Total nitrogen (TN), activity and selectivity for the reduction of nitrate are defined by the following equations:

$$
\begin{aligned}
& \mathrm{TN}=\mathrm{C}\left[\mathrm{NO}_{3}^{-}\right]_{t}+\mathrm{C}\left[\mathrm{NO}_{2}^{-}\right]_{t}+\mathrm{C}\left[\mathrm{NH}_{4}^{+}\right]_{t} \\
& \text { Activity }=\left(\mathrm{C}\left[\mathrm{NO}_{3}^{-}\right]_{0}-\mathrm{C}\left[\mathrm{NO}_{3}^{-}\right]_{t}\right) /(t \cdot m) \\
& \text { Selectivity }=1-\left(\mathrm{C}\left[\mathrm{NO}_{2}^{-}\right]_{t}+\mathrm{C}\left[\mathrm{NH}_{4}^{+}\right]_{t}\right) /\left(\mathrm{C}\left[\mathrm{NO}_{3}^{-}\right]_{0}-\mathrm{C}\left[\mathrm{NO}_{3}^{-}\right]_{t}\right)
\end{aligned}
$$

where $\mathrm{C}\left[\mathrm{NO}_{3}{ }^{-}\right]_{0}$ and $\mathrm{C}\left[\mathrm{NO}_{3}{ }^{-}\right]_{t}(\mathrm{mg}-\mathrm{N} / \mathrm{L})$ are the initial concentration of $\mathrm{NO}_{3}{ }^{-}-\mathrm{N}$ and that at time $\left.t ; \mathrm{C} \mathrm{NO}_{2}{ }^{-}\right]_{t}$ and $\mathrm{C}\left[\mathrm{NH}_{4}{ }^{+}\right]_{t}(\mathrm{mg}-\mathrm{N} / \mathrm{L})$ are the concentration of $\mathrm{NO}_{2}{ }^{-}-\mathrm{N}$ and $\mathrm{NH}_{4}{ }^{+}-\mathrm{N}$ at time $t ; t$ is the reaction time: $\mathrm{h} ; m$ is the catalyst-Pd dosage: $\mathrm{g} / \mathrm{L}$.

In each experiment described here, nitrogen and ammonium were the only two products after the complete conversion of nitrate, where nitrogen is the desired product, and ammonium is the undesired one. In addition, nitrite was a primary and unstable intermediate product. The selectivity for nitrate reduction is given by the fraction resulting in nitrogen, i.e., more ammonium formation means less selectivity for the reduction of nitrate in our experiment.

\section{Results and Discussion}

\subsection{Catalyst Characterization}

The characteristic parameters of $\mathrm{AC}$ and $\mathrm{Pd}-\mathrm{Sn} / \mathrm{AC}$ are summarized in Table 1. Obviously, the surface area was decreased from 1396 to $937 \mathrm{~m}^{2} / \mathrm{g}$ after impregnation due to $\mathrm{Pd}-\mathrm{Sn}$ deposition. Furthermore, introduction of active metals by wet-impregnation had no significant effect on the pore volume and pore diameter of AC. The large surface area of $937 \mathrm{~m}^{2} / \mathrm{g}$ should be favorable for nitrate reduction.

The TEM and SEM-EDX analysis of Pd-Sn/AC was shown in Fig. 2. As can be seen in Fig. 2a, the distribution of active metal $\mathrm{Pd}$ and $\mathrm{Sn}$ grains was uniform, the metal clusters were homogeneously dispersed on the AC support, and the size of metal Pd and $\mathrm{Sn}$ grains was about $8 \mathrm{~nm}$. The semi-quantitative EDX analysis (Fig. 2d) determined that the $\mathrm{Pd} / \mathrm{Sn}$ weight ratio was 4.21 , which is close to the nominal ratio of 4.0 .

Table 1 The characteristic parameters of AC and Pd-Sn/AC

\begin{tabular}{llll}
\hline Sample & $\begin{array}{l}\text { BET } \\
\left(\mathrm{m}^{2} / \mathrm{g}\right)\end{array}$ & $\begin{array}{l}\text { Average pore } \\
\text { volume }\left(\mathrm{cm}^{3} / \mathrm{g}\right)\end{array}$ & $\begin{array}{l}\text { Average pore } \\
\text { diameter }(\mathrm{nm})\end{array}$ \\
\hline $\mathrm{AC}$ & 1396 & 0.8302 & 2.569 \\
$\mathrm{Pd}-\mathrm{Sn} / \mathrm{AC}$ & 937 & 0.6671 & 2.570
\end{tabular}

$\mathrm{X}$-ray diffraction patterns of $\mathrm{AC}$ and $\mathrm{Pd}-\mathrm{Sn} / \mathrm{AC}$ were shown in Fig. 3. It can be seen that the XRD pattern of AC showed a significant $C$ peak at $26.2^{\circ}$ (noted with black diamond), while the XRD pattern of the catalyst showed other reflections at $20.1^{\circ}, 40.0^{\circ}, 46.6^{\circ}, 68.6^{\circ}, 82.2^{\circ}$ (noted with bullet) besides the $\mathrm{C}$ peak. The reflection at $20.1^{\circ}$ is attributed to $\mathrm{Sn}$ metal, and reflections at $40.0^{\circ}, 46.6^{\circ}, 68.6^{\circ}$, $82.2^{\circ}$ derive from $\mathrm{Pd}$ metal. Furthermore, two peaks overlapped at $40.0^{\circ}$; since the reported strongest peaks of $\mathrm{Pd}$ and Sn metal appear at $40.0^{\circ}$ and $39.2^{\circ}$, it was speculated that this overlapped peak derives from these strong $\mathrm{Pd}$ and Sn peaks. In addition, Scherrer's method was explored to calculate the grain size of Pd and Sn metal $(d=\lambda /$ $\beta \cos \theta, \lambda$ is the $\mathrm{X}$-ray wavelength, $\beta$ is the peak width at half maximum). The $d$ values of the $20.1^{\circ}, 40.0^{\circ}, 46.6^{\circ}$, $68.6^{\circ}$, and $82.2^{\circ}$ peaks were $7.91,6.63,6.11,6.79$, and $7.45 \mathrm{~nm}$, respectively. The calculated $d$ values were in accordance with the TEM analysis; Pd-Sn alloy with cubic phase was in a highly dispersed state, which would facilitate nitrate reduction [24].

\subsection{Electroreduction of Nitrate}

In the reactor, nitrate ions were reduced in the cathode cell compartment of the system. First, water molecules were reduced on the cathode surface:

$\mathrm{H}_{2} \mathrm{O}+e^{-} \rightarrow \mathrm{H}_{(\mathrm{ads})}+\mathrm{OH}^{-}$

where the subscript (ads) refers to adsorbed species and the produced $\mathrm{H}_{(\text {ads }}$ species could undergo a recombination reaction and thus lead to the evolution of hydrogen gas:

$\mathrm{H}_{(\mathrm{ads})}+\mathrm{H}_{(\mathrm{ads})} \rightarrow \mathrm{H}_{2 \text { (gas) }}$

Meanwhile, the nitrate ions in the solution phase $\left(\mathrm{NO}_{3}{ }^{-}\right.$(sol) $)$could be adsorbed onto the suspended catalyst active site and then reduced by $\mathrm{H}_{(\mathrm{ads})}$ :

$\mathrm{NO}_{3(\text { sol })}^{-} \rightarrow \mathrm{NO}_{3(\text { ads })}^{-}$

$\mathrm{NO}_{3(\text { ads })}^{-}+2 \mathrm{H}_{(\text {ads })} \rightarrow \mathrm{NO}_{2(\mathrm{ads})}^{-}+\mathrm{H}_{2} \mathrm{O}$

The $\mathrm{NO}_{2}{ }^{-}$(ads) species may be desorbed away from the catalyst surface to the solution phase or it may be further reduced according to:

$\mathrm{NO}_{2(\mathrm{ads})}^{-}+\mathrm{H}_{(\mathrm{ads})} \rightarrow \mathrm{NO}_{(\mathrm{ads})}+\mathrm{OH}^{-}$

Adsorbed $\mathrm{NO}_{(\mathrm{ads})}$ might be released into solution by desorption:

$\mathrm{NO}_{(\mathrm{ads})} \rightarrow \mathrm{NO}_{(\mathrm{sol})}$

High adsorption energy will lead to low adsorption onto the metal surface [25], actually. Only a few NO molecules are released into solution. Subsequently, $\mathrm{NO}_{(\mathrm{ads})}$ would further be reduced to $\mathrm{N}_{2} \mathrm{O}$, and the final product could be $\mathrm{N}_{2}$ or $\mathrm{NH}_{4}^{+}$: 

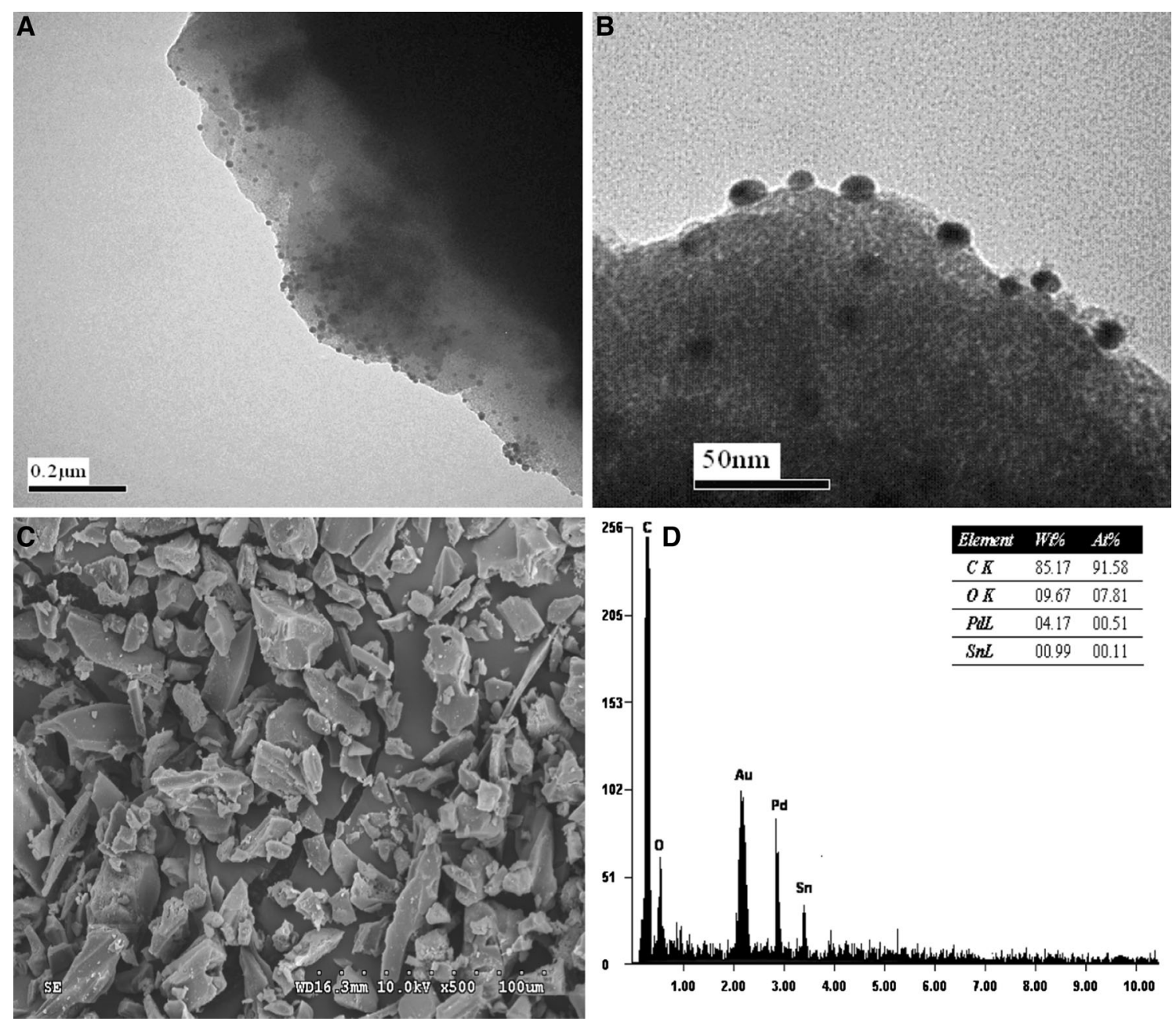

Fig. 2 TEM images (a and b) and SEM-EDX analysis of Pd-Sn/AC (c and d)

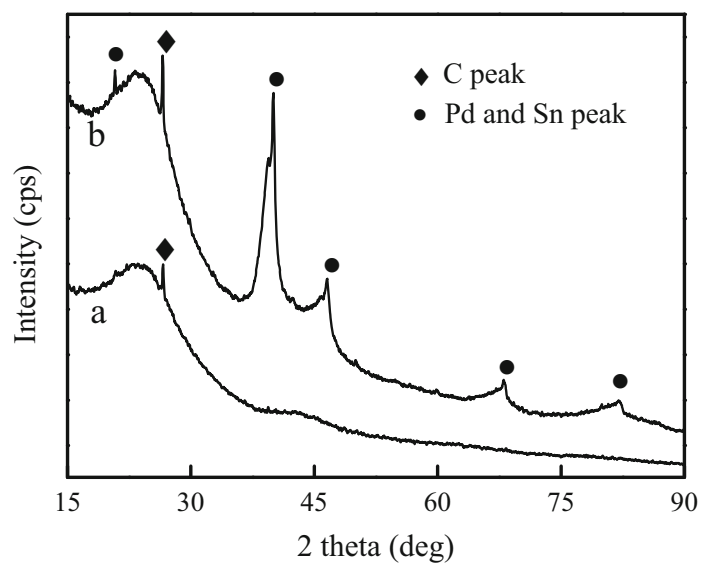

Fig. 3 XRD patterns of $a \mathrm{AC}$ and $b \mathrm{Pd}-\mathrm{Sn} / \mathrm{AC}$

$$
\begin{aligned}
& 2 \mathrm{NO}_{(\mathrm{ads})}+2 \mathrm{H}^{+}+2 e^{-} \rightarrow \mathrm{N}_{2} \mathrm{O}+\mathrm{H}_{2} \mathrm{O} \\
& \mathrm{N}_{2} \mathrm{O}+2 \mathrm{H}^{+}+2 e^{-} \rightarrow \mathrm{N}_{2}+\mathrm{H}_{2} \mathrm{O} \\
& \mathrm{NO}_{(\mathrm{ads})}+4 \mathrm{H}^{+}+4 e^{-} \rightarrow \mathrm{NH}_{3} \mathrm{OH}
\end{aligned}
$$

$\mathrm{NO}_{(\text {ads })}+6 \mathrm{H}^{+}+5 e^{-} \rightarrow \mathrm{NH}_{4}^{+}+\mathrm{H}_{2} \mathrm{O}$

For the anode reaction:

$$
\mathrm{H}_{2} \mathrm{O} \rightarrow 1 / 2 \mathrm{O}_{2}+2 \mathrm{H}^{+}+2 e^{-}
$$

In this study, the Pd-Sn/AC was used not only as catalyst but also as particle electrode. As shown in Fig. 1, Pd$\mathrm{Sn} / \mathrm{AC}$ particles were suspended in the cathode cell compartment, and a micro-electrolysis reaction could take place on the particles under the electric field. $\mathrm{H}_{(\mathrm{ads})}$ might be generated at the cathodic side of the particle electrode and hence could be utilized conveniently in the reduction process. The presence of $\mathrm{Pd}-\mathrm{Sn}$ nanoparticles played a significant role in forming $\mathrm{H}^{*}$ to realize a high removal efficiency of nitrate. Consequently, the applied current was mainly divided into reactive current and pathway current.

During the electro-catalytic reduction process, the changes of nitrate, nitrite and ammonium ions are shown in Fig. 4. At an applied current of $30 \mathrm{~mA}$, and electro-catalyst dosage of $7.5 \mathrm{~g} / \mathrm{L}$, the $\mathrm{NO}_{3}{ }^{-}-\mathrm{N}$ concentration decayed rapidly from 24.6 to $2.45 \mathrm{mg} / \mathrm{L}$ after $80 \mathrm{~min}$ reaction, i.e. 

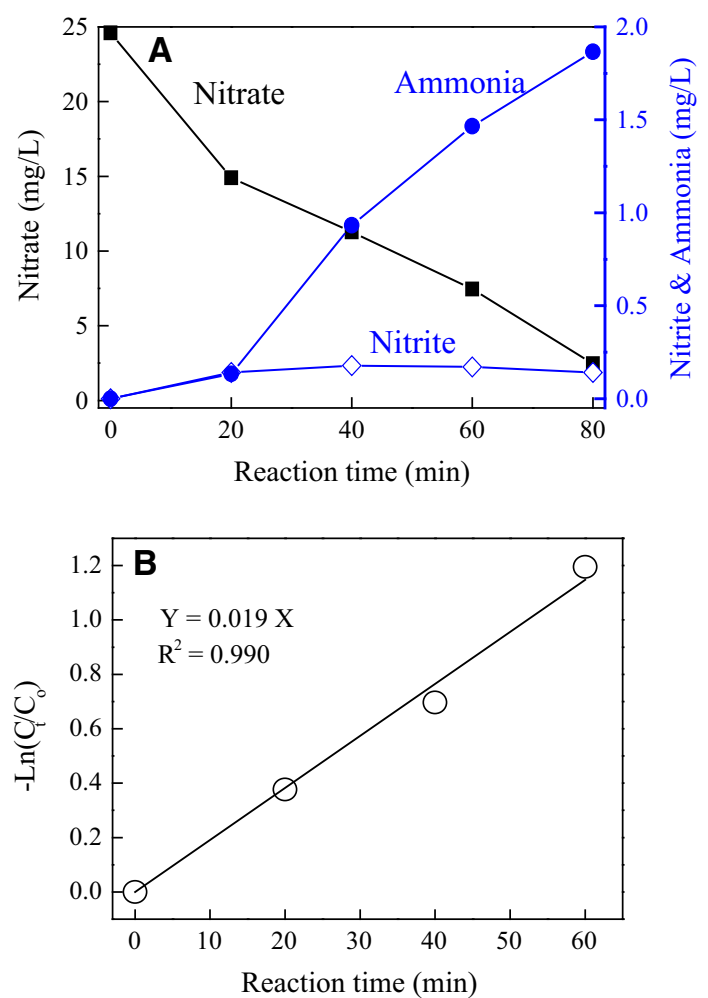

Fig. 4 A typical reaction profile for the electro-catalytic reduction of $\mathrm{NO}_{3}{ }^{-}-\mathrm{N}$ and the generation of $\mathrm{NO}_{2}{ }^{-}-\mathrm{N}$ and $\mathrm{NH}_{4}{ }^{+}$over $\mathrm{Pd}-\mathrm{Sn} / \mathrm{AC}$ (a) and the first-order kinetic model fitting of nitrate concentration versus reaction time $(\mathbf{b}) .(\mathrm{pH} 7.11, \mathrm{Pd}-\mathrm{Sn} / \mathrm{AC}=7.5 \mathrm{~g} / \mathrm{L}, \mathrm{I}=30 \mathrm{~mA}$, initial $\mathrm{NO}_{3}{ }^{-}-\mathrm{N}$ concentration $=24.6 \mathrm{mg} / \mathrm{L}$ )

$90.0 \%$ of nitrate anions were reduced. Moreover, the nitrate reduction followed the first order kinetics with the reaction constant of $0.019 \mathrm{~min}^{-1}$. Intermediates of nitrite and final product of ammonium ions were also observed. As shown in Fig. 4a, the nitrite concentration increased initially, reached a maximum concentration at $40 \mathrm{~min}$ reaction at $54.15 \%$ nitrate conversion, and then decreased. While ammonium concentration always increased throughout the reaction time. After $80 \mathrm{~min}$ reaction, the concentration of $\mathrm{NO}_{2}{ }^{-}-\mathrm{N}$ and $\mathrm{NH}_{4}{ }^{+}-\mathrm{N}$ reached 0.14 and $1.86 \mathrm{mg} / \mathrm{L}$, respectively. $\mathrm{TN}$ in the solution decreased from 24.6 to $4.45 \mathrm{mg} / \mathrm{L}$, which was composed of $2.45 \mathrm{mg} / \mathrm{L}$ $\mathrm{NO}_{3}{ }^{-}-\mathrm{N}, 0.14 \mathrm{mg} / \mathrm{L} \mathrm{NO}_{2}{ }^{-}-\mathrm{N}$ and $1.86 \mathrm{mg} / \mathrm{L} \mathrm{NH}_{4}{ }^{+}-\mathrm{N}$. Hence, the main product of nitrate reduction should be nitrogen and the selectivity and activity of $\mathrm{Pd}-\mathrm{Sn} / \mathrm{AC}$ for nitrate to nitrogen was $90 \%$ and $54.27 \mathrm{mg} \mathrm{NO}_{3}{ }^{-}-\mathrm{N} /$ $\left(g_{\mathrm{Pd}-\mathrm{Sn}} \cdot \mathrm{h}\right)$.

\subsection{Effect of Applied Current}

The effect of electrical current on the nitrate reduction was explored in this study varied from 10 to $50 \mathrm{~mA}$ since the rate of reductant (electron or hydrogen atom) supply was

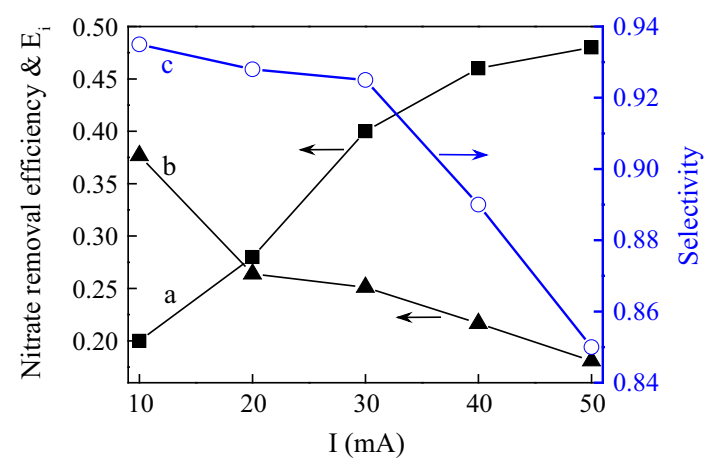

Fig. 5 Effect of current density on the efficiency of electro-catalytic reduction of nitrate: $\mathbf{a}$ nitrite removal efficiency; $\mathbf{b}$ current efficiency $E_{\mathrm{i}}$; c selectivity $\left(\mathrm{pH} 7.11, \mathrm{Pd}-\mathrm{Sn} / \mathrm{AC}=7.5 \mathrm{~g} / \mathrm{L}\right.$, initial $\mathrm{NO}_{3}{ }^{-}-\mathrm{N}$ concentration $=24.6 \mathrm{mg} / \mathrm{L}$, reaction time $=30 \mathrm{~min}$ )

affected by the electrical current. Effective current $\left(I_{\mathrm{E}}\right)$ was calculated using the following equation:

$$
\begin{aligned}
I_{\mathrm{E}}= & \left(\mathrm{C}\left[\mathrm{NO}_{3}^{-}\right]_{0}-\mathrm{C}\left[\mathrm{NO}_{3}^{-}\right]_{t}\right) \times 5 \\
& +\left(\mathrm{C}\left[\mathrm{NO}_{2}^{-}\right]_{0}-\mathrm{C}\left[\mathrm{NO}_{2}^{-}\right]_{t}\right) \times 3 \\
& +\left(\mathrm{C}\left[\mathrm{NH}_{4}^{-}\right]_{0}-\mathrm{C}\left[\mathrm{NH}_{4}^{-}\right]_{t}\right) \times F \times V / t
\end{aligned}
$$

where $C$ is $\mathrm{NO}_{3}^{-}-\mathrm{N}, \mathrm{NO}_{2}^{-}-\mathrm{N}$ or $\mathrm{NH}_{4}^{+}-\mathrm{N}$ concentration (mmol-N/L), $F$ is the Faraday constant $(26.8 \mathrm{~mA} \mathrm{~h} / \mathrm{mmol}$ ), $V$ is the effective volume of the reactor (L) and $t$ is the reaction time $(\mathrm{h})$. The electric current efficiency can be calculated as: $E_{\mathrm{i}}=I_{\mathrm{E}} / I$.

It can be seen in Fig. 5 that the nitrate removal efficiency exhibited an increasing tendency along with the increase of the applied current. The increased $\mathrm{H}$ supply could promote the nitrate reduction. However, the promotion weakened when the applied current exceeded $30 \mathrm{~mA}$. Meanwhile, with increasing applied current, the current efficiency exhibited a decreasing trend and the $\mathrm{NH}_{4}{ }^{+}-\mathrm{N}$ concentration exhibited an increasing trend. As the applied current increased from 10 to $50 \mathrm{~mA}$, the $\mathrm{NH}_{4}{ }^{+}-\mathrm{N}$ concentration increased from 0.28 to $1.53 \mathrm{mg} / \mathrm{L}$. Correspondingly, the selectivity decreased from 93.5 to $85.1 \%$. Under higher applied current conditions, both the reaction current and the bypass current increase, therefore the production of hydrogen speeds up. Excess hydrogen is not conducive to the formation of $\mathrm{N} \equiv \mathrm{N}$, but promotes $\mathrm{N}-\mathrm{H}$ bonding.

\subsection{Effect of Initial Nitrate Concentration}

The effect of initial nitrate concentration on nitrate removal and $\mathrm{E}_{\mathrm{i}}$ was explored with the initial $\mathrm{NO}_{3}{ }^{-}-\mathrm{N}$ concentration fixed at $14.8,24.6,32.6$ and $39.8 \mathrm{mg} / \mathrm{L}$. The removed nitrate concentration and corresponding current efficiency $E_{\mathrm{i}}$ after $20 \mathrm{~min}$ reaction are represented in Fig. 6a. Along with the increase of the initial nitrate concentration, the 

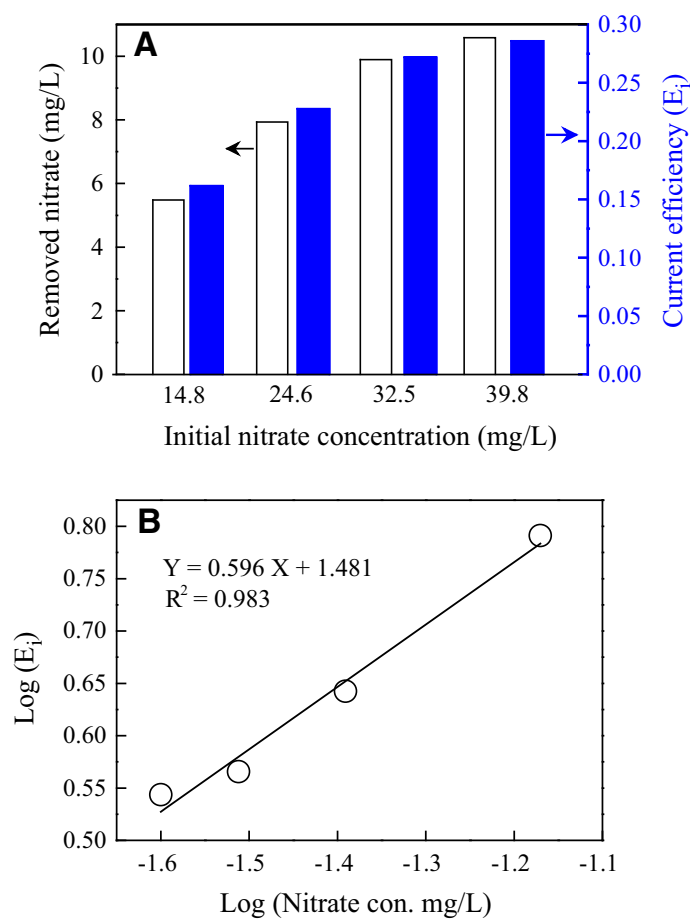

Fig. 6 a Effect of initial nitrate concentration on nitrate removal and $E_{\mathrm{i}}$; b first-order kinetic model fitting of current efficiency versus nitrate concentration (initial $\mathrm{pH} 7.11, \mathrm{Pd}-\mathrm{Sn} / \mathrm{AC}=7.5 \mathrm{~g} / \mathrm{L}$, $\mathrm{I}=30 \mathrm{~mA}$, reaction time $=30 \mathrm{~min}$ )

nitrate removal efficiency and $E_{\mathrm{i}}$ increased notably. When the initial $\mathrm{NO}_{3}{ }^{-}-\mathrm{N}$ concentration increased from 14.8 to $39.8 \mathrm{mg} / \mathrm{L}$, the reduced nitrate concentration varied from 5.48 to $10.58 \mathrm{mg} / \mathrm{L}$, the removal amount was nearly doubled, and $E_{\mathrm{i}}$ also rose from 17.1 to $29.6 \%$. Moreover, as shown in Fig. 6b, the relationship of current efficiency vs nitrate concentration could be satisfactorily described with a first-order kinetic model with a high correlation coefficient $\left(k=0.596, R^{2}=0.983\right)$. The results suggested that more nitrate anions could interact with the active sites of $\mathrm{Pd}-\mathrm{Sn} / \mathrm{AC}$ by Brownian motion with the increase of initial nitrate concentration, which results in the higher removal efficiency of nitrate reduced by $H_{(\text {ads })}$. The current efficiency, $E_{i}$, was hence enhanced.

\subsection{Effect of Initial pH Value}

As shown in Table 2, the effect of initial $\mathrm{pH}$ on nitrate removal was explored at initial $\mathrm{pH}$ values of 3.97, 7.11 and

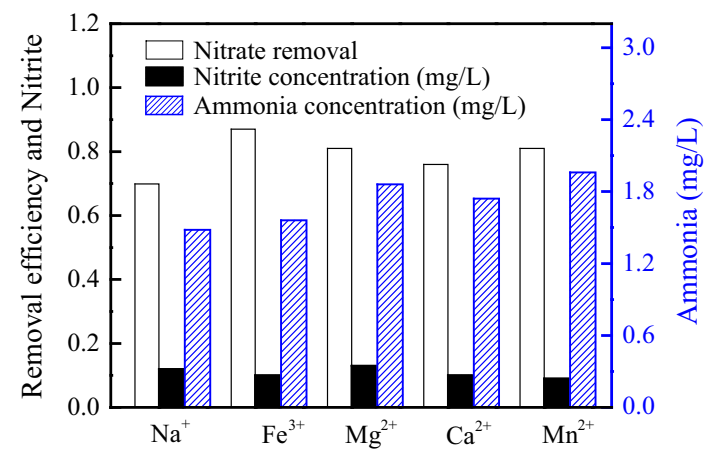

Fig. 7 Effect of common cations on electro-catalytic nitrogen removal (initial $\mathrm{NO}_{3}{ }^{-}-\mathrm{N}$ concentration $=24.6 \mathrm{mg} / \mathrm{L}, \quad \mathrm{Pd}-\mathrm{Sn} /$ $\mathrm{AC}=7.5 \mathrm{~g} / \mathrm{L}, I=30 \mathrm{~mA}$, reaction time $=40 \mathrm{~min}$ )

9.03. Dilute $\mathrm{H}_{2} \mathrm{SO}_{4}$ and $\mathrm{NaOH}$ solutions were used for $\mathrm{pH}$ adjustments.

The nitrate removal efficiency, $\mathrm{NO}_{2}{ }^{-}-\mathrm{N}$ and $\mathrm{NH}_{4}{ }^{+}-\mathrm{N}$ concentrations, corresponding catalyst selectivity and current efficiency $E_{\mathrm{i}}$ after $30 \mathrm{~min}$ reaction were monitored. The nitrate removal efficiency increased from 25.07 to $58.55 \%$ when the initial $\mathrm{pH}$ decreased from 9.03 to 3.97 . Moreover, there was no significant difference in the nitrite and ammonia generation by changing the solution $\mathrm{pH}$, while the current efficiency and selectivity of $\mathrm{Pd}-\mathrm{Sn} / \mathrm{AC}$ was greatly inhibited when the $\mathrm{pH}$ increased to 9.03. The results indicated that acid or neutral $\mathrm{pH}$ conditions will facilitate safe nitrate reduction to nitrogen.

\subsection{Effect of Co-existing Ions}

In actual water, there are many co-existing cations such as $\mathrm{Ca}^{2+}, \mathrm{Mg}^{2+}, \mathrm{Mn}^{2+}, \mathrm{Fe}^{3+}, \mathrm{Na}^{+}$and co-existing anions such as $\mathrm{Cl}^{-}, \mathrm{SO}_{4}{ }^{2-}, \mathrm{HCO}_{3}{ }^{-}$. Figure 7 depicted the effect of coexisting cations on the nitrate reduction and the corresponding nitrite and ammonia generation. Apparently, the nitrate removal efficiency decreased in the following order: $\mathrm{Fe}^{3+}>\mathrm{Mn}^{2+}>\mathrm{Mg}^{2+}>\mathrm{Ca}^{2+}>\mathrm{Na}^{+}$and its removal efficiency was the lowest in the presence of $\mathrm{Na}^{+}$. It was reported that the nitrate reduction efficiency and the selectivity to $\mathrm{N}_{2}$ was limited by diffusion [26]. While $\mathrm{OH}^{-}$ ions were produced as by-products continuously and competed with nitrate for the active sites on the surface of the catalyst. Hence, the faster removal of $\mathrm{OH}^{-}$ions from the catalyst surface could promote the regeneration of active sites. Different cations have different affinities
Table 2 Effect of initial $\mathrm{pH}$ on nitrate reduction $(\mathrm{Pd}-\mathrm{Sn} /$ $\mathrm{AC}=7.5 \mathrm{~g} / \mathrm{L}, I=30 \mathrm{~mA}$, reaction time $=30 \mathrm{~min}$ )

\begin{tabular}{llllll}
\hline $\mathrm{pH}$ & $\mathrm{NO}_{3}{ }^{-}$removal $(\%)$ & $\mathrm{NO}_{2}{ }^{-}(\mathrm{mg} / \mathrm{L})$ & $\mathrm{NH}_{4}{ }^{+}(\mathrm{mg} / \mathrm{L})$ & $\mathrm{E}_{\mathrm{i}}$ & Selectivity (\%) \\
\hline 3.97 & 58.55 & 0.12 & 1.33 & 0.19 & 89.9 \\
7.11 & 50.18 & 0.15 & 0.93 & 0.17 & 91.24 \\
9.03 & 25.07 & 0.20 & 0.80 & 0.08 & 83.80 \\
\hline
\end{tabular}



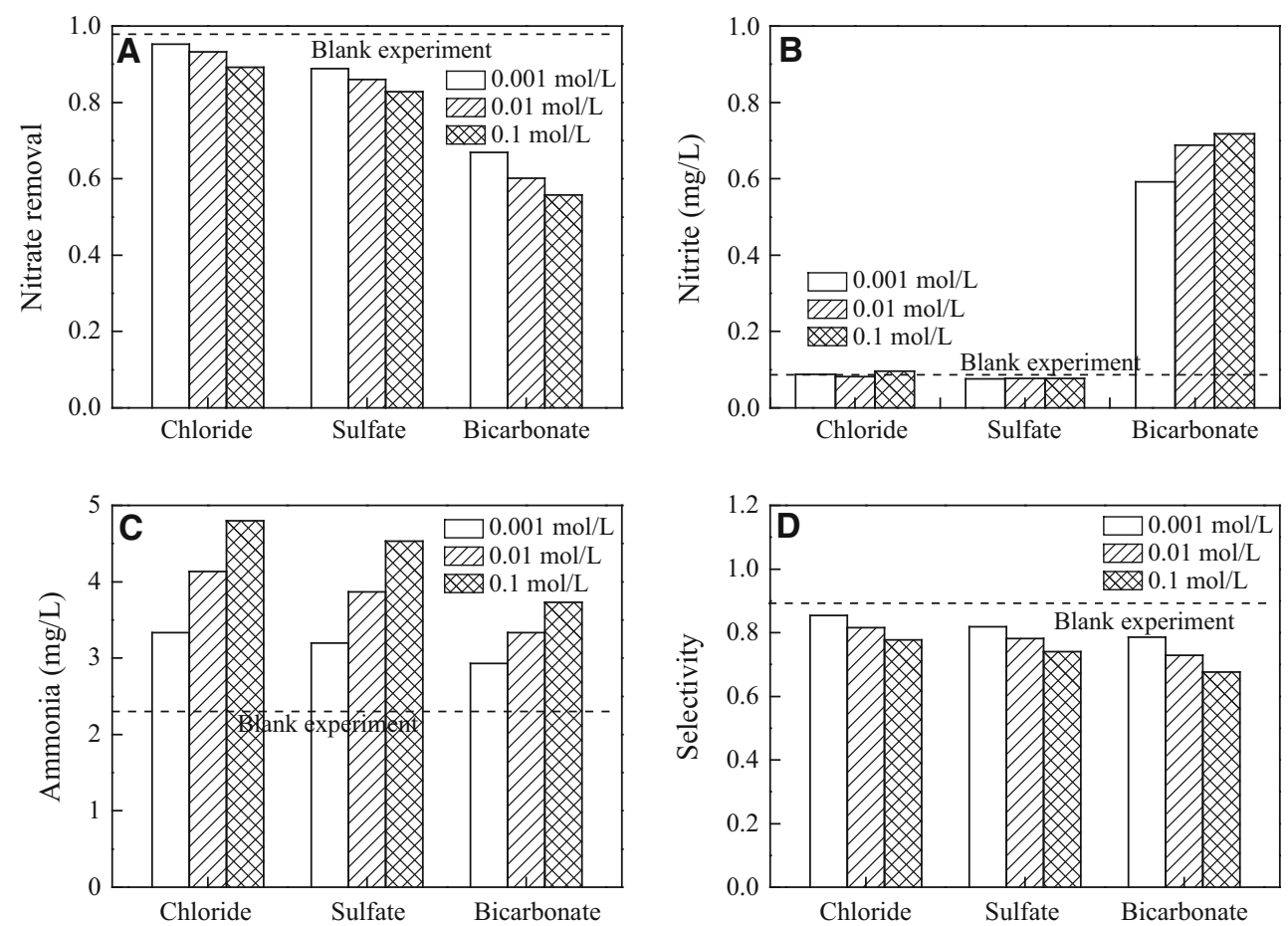

Fig. 8 Effect of common anions on $\mathbf{a ~} \mathrm{NO}_{3}{ }^{-}-\mathrm{N}$ removal efficiency; $\mathbf{b ~} \mathrm{NO}_{2}{ }^{-}-\mathrm{N}$ concentration; $\mathbf{c} \mathrm{NH}_{4}{ }^{+}-\mathrm{N}$ concentration; $\mathbf{d}$ selectivity of electrocatalytic nitrogen removal (initial $\mathrm{NO}_{3}{ }^{-}-\mathrm{N}$ concentration $=24.6 \mathrm{mg} / \mathrm{L}, \mathrm{Pd}-\mathrm{Sn} / \mathrm{AC}=7.5 \mathrm{~g} / \mathrm{L}, \mathrm{I}=30 \mathrm{~mA}$, reaction time $=80 \mathrm{~min}$ )

toward $\mathrm{OH}^{-}$and thus influence the nitrate reduction. In this study, the solubility constants for hydroxide precipitation vary according to the following order: $\mathrm{Fe}(\mathrm{OH})_{3}<$ $\mathrm{Mn}(\mathrm{OH})_{2}<\mathrm{Mg}(\mathrm{OH})_{2}<\mathrm{Ca}(\mathrm{OH})_{2}<\mathrm{NaOH}$, which indicates that the cation affinity toward $\mathrm{OH}^{-}$decreases in the order: $\mathrm{Fe}^{3+}>\mathrm{Mn}^{2+}>\mathrm{Mg}^{2+}>\mathrm{Ca}^{2+}>\mathrm{Na}^{+}, \quad$ which agreed well with their influence on the nitrate removal efficiency.

Figure 8 further exhibited the effect of common co-existing anions on nitrate removal. The results indicated that the negative influence of selected anions on nitrate reduction followed this order: $\mathrm{Cl}^{-}<\mathrm{SO}_{4}{ }^{2-}<\mathrm{HCO}_{3}{ }^{-}$. In addition, the inhibitory effects became more significant with the increase of anion concentration. In comparison with $\mathrm{Cl}^{-}$and $\mathrm{SO}_{4}{ }^{2-}$, the higher inhibition caused by $\mathrm{HCO}_{3}{ }^{-}$should be attributed to its $\mathrm{pH}$ buffer since the nitrate reduction could be greatly decreased at higher $\mathrm{pH}$. Moreover, the selectivity of $\mathrm{Pd}-\mathrm{Sn} / \mathrm{AC}$ was also decreased in the presence of co-existing anion because of the competition in interacting with active sites.

\section{Conclusions}

Highly dispersed $\mathrm{Pd}-\mathrm{Sn}$ on $\mathrm{AC}(\mathrm{Pd}-\mathrm{Sn} / \mathrm{AC})$ was successfully prepared via impregnation method. It was used as catalyst and particle electrodes in the electro-catalytic process, over $90 \%$ of nitrate could be removed in $80 \mathrm{~min}$ at an applied current of $30 \mathrm{~mA}$ and an electro-catalyst dosage of $7.5 \mathrm{~g} / \mathrm{L}$. With an increase in the applied current, the nitrate removal efficiency and $\mathrm{NH}_{4}{ }^{+}-\mathrm{N}$ concentration appeared to increase, whereas the current efficiency showed a decreasing trend. The nitrate electro-catalysis process could be satisfactorily described with a first-order kinetics model; the nitrate reduction efficiency was limited by diffusion. The co-existing anions $\mathrm{Cl}^{-}, \mathrm{SO}_{4}{ }^{2-}$ and $\mathrm{HCO}_{3}{ }^{-}$suppressed the reduction of nitrate, with $\mathrm{HCO}_{3}{ }^{-}$ appearing to cause the most significant inhibition.

Acknowledgments This research was supported by the Funds of the National Natural Science Foundation of China (Grant Nos. 51478455 and 51221892).

\section{References}

1. United States Environmental Protection Agency (2000) National Water Quality Inventory; EPA 816-R-00-013; USEPA Office of Water: Washington, DC

2. Canter LW (1996) Nitrates in groundwater. CRC Press, Boca Raton

3. Nolan BT, Ruddy BC, Hitt KJ, Helsel DR (1997) Environ Sci Technol 31:2229-2236

4. Tepuš B, Simonič M, Petrinić I (2009) J Hazard Mater 170:1210-1217

5. Samatya S, Kabay N, Yüksel U, Arda M, Yüksel M (2006) React Funct Polym 66:1206-1214 
6. Rezania B, Oleszkiewicz JA, Cicek N (2007) Water Res 41:1074-1080

7. Moon HS, Ahn K-H, Lee S, Nam K, Kim JY (2004) Environ Pollut 129:499-507

8. Vorlop KD, Tacke T (1989) Chem Ing Tech 61:836-845

9. Prüsse U, Hähnlein M, Daum J, Vorlop K (2000) Catal Today 55:79-90

10. Mikami I, Kitayama R, Okuhara T (2006) Appl Catal A 297:24-30

11. Pintar A (2003) Catal Today 77:451-465

12. Sá J, Vinek H (2005) Appl Catal B 57:247-256

13. Nakamura K, Yoshida Y, Mikami I (2006) Appl Catal B 65:31-36

14. Maia MP, Rodrigues MA, Passos FB (2007) Catal Today 123:171-176

15. Wan D, Liu H, Zhao X, Qu J, Xiao S, Hou Y (2009) Colloid Interface Sci 332:151-157

16. Peel JW, Reddy KJ, Sullivan BP, Bowen JM (2003) Water Res 37:2512-2519
17. Dima GE, Vooys ACA (2003) Electroanal Chem 554-555:15-23

18. Kerkeni S, Lamy-Pitara E, Barbier J (2002) Catal Today 75:35-42

19. Vooys ACA, Santen RA, Veen JAR (2000) J Mol Catal A 154:203-215

20. Gootzen JFE, Lefferts L, Veen JAR (1999) Appl Catal A 188:127-136

21. Tenne R, Patel K, Hashimoto K, Fujishima A (1993) J Electroanal Chem 347:409-415

22. Shimazu K, Goto R, Keijiro T (2002) Chem Lett 31:204-205

23. Wang Y, Qu J, Wu R, Lei P (2006) Water Res 40:1224-1232

24. Arana J, Ramirez de la Piscina P, Llorca J, Sales J, Homs N (1998) Chem Mater 10:1333-1342

25. Beck DE, Heitzinger JM, Avoyan A, Koel BE (2001) Surf Sci 491(1-2):48-62

26. Prusse U, Vorlop KD, Mol J (2001) Catal A 173:313-328 